\title{
FAKTOR-FAKTOR YANG MEMENGARUHI KECEMASAN DALAM MENGHADAPI MENOPAUSE DI DESA MEUNASAH DAYAH KECAMATAN PEUSANGAN KABUPATEN BIREUEN
}

\section{Factors that Influence Anxiety In Facing Menopause in The Village of Meunasah Dayah Peusangan Sub-district In Bireuen District}

\author{
Minda Septiani*1, Cut Muslihati*2 \\ 1. Dosen Akademi Kebidanan Munawarah, Jl. Sultan Iskandar Muda No.18 Kota Juang, Bireuen 24251, Indonesia \\ 2. Mahasiswi Akademi Kebidanan Munawarah, Jl. Sultan Iskandar Muda No.18 Kota Juang, Bireuen 24251, \\ Indonesia
}

*Korespondensi Penulis : mindaseptiani88@gmail.com*1

\begin{abstract}
Abstrak
Kecemasan akan datangnya masa menopause umumnya terjadi pada perempuan yang memasuki usia 50 tahun. Rasa takut yang dialami oleh wanita antara lain, kecantikan memudar dan rasa khawatir akan kehilangan suami karena gairah seksual menurun. Setelah usia 45 tahun, seorang perempuan masih mengalami menstruasi tetapi tidak teratur lagi, sebagian perempuan telah mengalami gejala pre menopause. Penelitian ini dilakukan untuk mengetahui faktor-faktor yang memengaruhi kecemasan dalam menghadapi menopause di Desa Meunasah Dayah Kecamatan Peusangan Kabupaten Bireuen.

Desain penelitian yang digunakan adalah penelitian analitik dengan pendekatan cross sectional. Penelitian ini telah dilakukan pada bulan Mei 2019. Populasi dalam penelitian ini adalah seluruh ibu premenopause yang berumur antara 40 sampai 50 tahun. Teknik pengambilan sampel yaitu dengan cara total sampling yang diperoleh dengan melakukan kunjungan rumah (door to door) sebanyak 163 orang.

Dari hasil penelitian, menunjukkan menunjukkan nilai $\mathrm{p}(0,025)<\mathrm{p}$ value $(0,05)$ berarti ha diterima dan ho ditolak, artinya ada pengaruh antara pengetahuan dengan kecemasan dalam menghadapi menopause. Hasil perhitungan menunjukkan nilai $\mathrm{p}(0,182)>\mathrm{p}$ value $(0,05)$ berarti h0 diterima dan ha ditolak, artinya tidak ada pengaruh antara perubahan fisik dengan kecemasan dalam menghadapi menopause. Hasil perhitungan menunjukkan nilai p $(0,009)<$ $\mathrm{p}$ value $(0,05)$ berarti ha diterima dan ho ditolak, artinya ada pengaruh antara dukungan keluarga dengan kecemasan dalam menghadapi menopause.

Diharapkan kepada responden agar meningkatkan lagi pengetahuan khususnya tentang tanda serta gejala yang terjadi menjelang menopause sehingga dapat mengurangi rasa cemas dan khawatir yang dirasakan.
\end{abstract}

Kata Kunci : Kecemasan, Pengetahuan, Perubahan Fisik, Dukungan Keluarga 
Journal of Healthcare Technology and Medicine Vol. 5 No. 2 Oktober 2019

Universitas Ubudiyah Indonesia

e-ISSN : 2615-109X

\begin{abstract}
Anxiety about the onset of menopause generally occurs in women entering the age of 50 years. Fear experienced by women, among others, faded beauty and fear of losing her husband because of decreased sexual desire. After the age of 45 years, a woman is still menstruating but is no longer organized, some women have experienced pre-menopausal symptoms. This research was conducted to find out the factors that influence anxiety in facing menopause in Meunasah Dayah Village, Peusangan District, Bireuen Regency.

The research design used was analytic research with cross sectional approach. This research was conducted on 9 to 11 May 2019. The population in this study were all premenopausal mothers aged 40 to 50 years. The sampling technique is by total sampling obtained by conducting house to door visits of 163 people.

From the results of the study, showed that the value of $p(0.025)<p$ value (0.05) means that ha is accepted and ho is rejected, meaning that there is an influence between knowledge and anxiety in the face of menopause. The calculation results show the value of $p(0.182)>p$ value (0.05) means that ho is accepted and ha is rejected, meaning that there is no influence between physical changes with anxiety in the face of menopause. The calculation results show the value of $p(0.009)<p$ value (0.05) means that ha is accepted and ho is rejected, meaning that there is an influence between family support and anxiety in the face of menopause.

It is expected that respondents will increase their knowledge, especially about the signs and symptoms that occur before menopause so that it can reduce the anxiety and anxiety felt.
\end{abstract}

Keywords: Anxiety, Knowledge, Physical Change, Family Support

\title{
PENDAHULUAN
}

Pada dasarnya kaum wanita memiliki dua fase dalam kehidupannya yaitu haid pertama (menarche) dan menstruasi terakhir (menopause). Dua fase ini memiliki begitu banyak kesamaan proses yang bertahap dan akan dilalui kaum wanita karena keduanya berkaitan dengan hormone estrogen, selain itu fase ini juga merupakan suatu ada saat wanita telah memasuki tahapan menopause kadar esterogen dan progeteron berangsur turun sehingga ikut mempengaruhi hormon lainnya. Kondisi inilah yang sering mengakibatkan banyak wanita pengalami sejumlah gejala klinis dan psikologis yang mengganggu aktifitas sehari-hari serta menimbulkan dampak negatif terhadap kualitas hidup dan rasa percaya diri (Lusiana, 2014).

Menurut Badan Pusat Statistik di Australia jumlah wanita menopause sekitar 2.130 wanita. Sementara itu tiap tahunnya, sekitar 25 juta wanita di seluruh dunia diperkirakan mengalami menopause. Jumlah wanita usia 50 tahun keatas diperkirakan meningkat dari 500 juta pada saat ini menjadi lebih dari 1 miliar pada tahun 2020. Di Asia, menurut data World Health Organization (WHO), pada tahun 2025 jumlah wanita yang berusia tua diperkirakan akan melonjak dari 107 juta menjadi 373 juta (Kulsum, 2017). 
Journal of Healthcare Technology and Medicine Vol. 5 No. 2 Oktober 2019

Universitas Ubudiyah Indonesia

e-ISSN : 2615-109X

Menopause merupakan suatu keadaan saat daur haid pada wanita berhenti. Hal ini disebabkan oleh lenyapnya folikel telur yang tersisa atau menjadi kurang sensitif terhadap perangsangan hormon otak FSH dan LH yang juga mengalami perubahan. Banyak istilah yang digunakan pada masa dewasa akhir dan salah satunya disebut awal menopause. Secara umum sebagian besar perempuan mulai memasuki masa menopause pada usia 49-52 tahun. Mengacu hasil penelitian bahwa usia harapan hidup perempuan Indonesia bertambah menjadi rata-rata 69 tahun. Maka sekitar 20-30 tahun atau sepertiga lama hidupnya, perempuan dalam keadaan menopause. Banyak dari ibu-ibu yang mengalami menopause menjadi seorang yang mudah mengalami rasa cemas. Akibat seringnya kekhawatiran yang menghantui dalam menghadapi situasi yang sebelumnya tidak pernah mereka khawatirkan, hal itu juga dapat menimbulkan kecemasan. Dampak menopause yang sering terjadi di masyarakat diantaranya kecemasan, takut, cepat marah, ingatannya menurun, sulit konsentrasi, gugup, merasa tidak berguna, mudah tersinggung, stress bahkan depresi (Kulsum, 2017).

Menopause menandai akhir masa reproduksi seorang wanita dan biasanya terjadi pada wanita berusia antara 45 dan 55 tahun dengan usia rata - rata 51 tahun. Berhentinya menstruasi disebabkan oleh berkurangnya sekresi hormon ovarium yang terjadi secara alami atau disebabkan oleh operasi, kemoterapi, atau radiasi. Menopause terjadi pada perempuan yang memasuki usia menjelang 50 tahun. Melalui usia tersebut bagian universal dan irreversibel dari keseluruhan proses penuaan yang melibatkan sistem reproduksi dimana siklus haid setiap bulannya mulai terganggu dan akhirnya menghilang sama sekali. Terganggunya atau sampai hilangnya proses haid pada wanita tersebut disebabkan penurunan dan hilangnya hormon estrogen, hal ini merupakan masalah yang normal, yang sadar atau tidak akan dilalui oleh perempuan dalam kehidupannya. Sehubungan menopause merupakan masalah normal sedangkan penerimaannya berbeda-beda diantara para perempuan maka alangkah baiknya masalah ini diketahui secara jelas oleh setiap perempuan (Nurpatminingsih, 2016).

Gejala yang menyertai pada kasus ini meliputi hot flushes (rasa panas dari dada hingga wajah) night sweat (berkeringat dimalam hari) dryness vaginal (kekeringan vagina), penurunan daya ingat, insomnia (susah tidur) depresi (rasa cemas) fatigue (mudah lelah) penurunan libido (gairah seks) dyspareunia (rasa sakit ketika berhubungan seksual) dan incontinence urinary (berer) (Kumalasari, 2012).

Perubahan kejiwaan yang dialami wanita menjelang menopause meliputi merasa tua, tidak menarik lagi, rasa tertekan karena takut menjadi tua, mudah tersinggung, mudah terkejut 
Journal of Healthcare Technology and Medicine Vol. 5 No. 2 Oktober 2019

Universitas Ubudiyah Indonesia

e-ISSN : 2615-109X

sehingga jantung berdebar-debar, takut tidak dapat memenuhi kebutuhan seksual suami, rasa takut bahwa suami akan menyeleweng, keinginan seksual menurun dan sulit mencapai orgasme. Mereka juga merasakan sudah tidak berguna lagi dan tidak menghasilkan sesuatu, merasa memberatkan keluarga dan orang lain, kemudian merasa depresi, kekhawatiran, perasaan ingin menangis dan mudah tersinggung (Rukiyah, 2012).

Kecemasan akan datangnya masa menopause umumnya terjadi pada perempuan yang memasuki usia 50 tahun. Rasa takut yang dialami oleh wanita antara lain, kecantikan memudar dan rasa khawatir akan kehilangan suami karena gairah seksual menurun. Setelah usia 45 tahun, seorang perempuan masih mengalami menstruasi tetapi tidak teratur lagi, sebagian perempuan telah mengalami gejala pre menopause. Masa menopause merupakan tahap akhir proses biologi yang berupa penurunan produksi hormon estrogen dari indung telur karena ovarium yang sudah tua. Dalam hal ini banyak faktor yang memengaruhi kecemasan dalam mengahadapi menopause seperti tingkat pengetahuan mengenai tanda-tanda serta perubahan selama menopause, dukungan dari anggota keluarga serta perubahan fisik yang terjadi akibat pengaruh hormone tersebut (Nurpatminingsih, 2016).

Pada saat wanita telah memasuki tahapan menopause kadar estrogen dan progeteron berangsur turun sehingga ikut mempengaruhi hormon lainnya. Kondisi inilah yang sering mengakibatkan banyak wanita pengalami sejumlah gejala klinis dan psikologis yang mengganggu aktifitas sehari-hari serta menimbulkan dampak negatif terhadap kualitas hidup dan rasa percaya diri. Ada beberapa hal yang erat kaitannya dengan kecemasan pada wanita di fase ini seperti pengetahuan tentang bagaimana serta ciri-ciri terjadinya menopause, perubahan fisik yang mengganggu pikirannya, serta dukungan keluarga dalam menghadapi menopause (Lusiana, 2014).

Di Indonesia, secara umum sebagian besar perempuan mulai memasuki masa menopause pada usia 49-52 tahun. Mengacu hasil penelitian bahwa usia harapan hidup perempuan Indonesia bertambah menjadi rata-rata 69 tahun. Maka sekitar 20-30 tahun atau sepertiga lama hidupnya, perempuan dalam keadaan menopause. Sindrom menopause dialami oleh hampir seluruh penduduk dunia, di Indonesia sekitar 10\% wanita menjelang menopause mengalami syndrome menopause. Diperkirakan jumlah orang yang menderita kecemasan baik akut maupun kronik mencapai 5\% dari jumlah penduduk dengan perbandingan wanita dengan pria $2: 1$ (Kulsum, 2017).

Dilihat dari klasifikasi jumlah penduduk di Indonesia, pada tahun terdapat 14.787.721 jiwa, jumlah wanita usia 45-49 tahun sebanyak 8.485.479 jiwa, usia 50-54 tahun sebanyak 
Journal of Healthcare Technology and Medicine Vol. 5 No. 2 Oktober 2019

Universitas Ubudiyah Indonesia

e-ISSN : 2615-109X

7.327.347 jiwa, usia 55-59 sebanyak 5.970.949 jiwa, 60-64 tahun 4.398.429 jiwa, 65-69 tahun sebanyak 3.084.716 jiwa, usia 70-74 sebanyak 2.208.376 jiwa dan 75 tahun keatas sebanyak 2.726.944 jiwa. Sedangkan di wilayah Provinsi Aceh, jumlah wanita usia non produktif sebanyak 209.607 jiwa (54,21\%) (Kemkes RI, 2017).

Berdasarkan hasil survey awal yang peneliti lakukan di Desa Meunasah Dayah Kecamatan Peusangan Kabupaten Bireuen, dari 10 ibu yang diwawancarai 8 dari mereka merasa khawatir akan perubahan kondisi tubuh mereka sekarang yang ditandai dengan susah tidur dimalam hari, mudah lelah, berkeringat dimalam hari, mengalami gangguan pada persendian, serta menstruasi yang sudah tidak datang lagi. Sedangkan 2 dari 10 orang yang diwawancarai mereka mengatakan tidak begitu menghiraukan akan kondisi badannya yang sekarang karena memang sudah waktunya akibat usia yang semakin menua.

Berdasarkan latar belakang diatas, maka peneliti tertarik untuk meneliti tentang "Faktor-faktor yang memengaruhi kecemasan dalam menghadapi menopause di Desa Meunasah Dayah Kecamatan Peusangan Kabupaten Bireuen”.

Berdasarkan latar belakang diatas, maka yang menjadi rumusan masalah dalam penelitian ini yaitu "Faktor-faktor apa saja yang memengaruhi kecemasan dalam menghadapi menopause di Desa Meunasah Dayah Kecamatan Peusangan Kabupaten Bireuen?”.

Tujuan penelitian ini untuk mengetahui faktor-faktor yang memengaruhi kecemasan dalam menghadapi menopause di Desa Meunasah Dayah Kecamatan Peusangan Kabupaten Bireuen.

\section{METODE PENELITIAN}

Penelitian ini menggunakan penelitian analitik dengan pendekatan cross sectional. Lokasi penelitian di lakukan di Desa Meunasah Dayah Kecamatan Peusangan Kabupaten Bireuen, dan waktu Penelitian ini dilakukan pada bulan Maret hingga Mei 2019. Populasi dalam penelitian ini adalah seluruh ibu premenopause yang berumur antara 40 sampai 50 tahun di Desa Meunasah Dayah Kecamatan Peusangan Kabupaten Bireuen. Sampel dalam penelitian ini adalah keseluruhan dari populasi yang berjumlah 163 orang. Data dianalisis secara univariat dan bivariat dengan menggunakan uji chi-Square pada taraf kepercayaan $95 \%(\mathrm{p}<0,05)$.

\section{HASIL PENELITIAN}


Journal of Healthcare Technology and Medicine Vol. 5 No. 2 Oktober 2019

Universitas Ubudiyah Indonesia

e-ISSN : 2615-109X

Analisis Univariat digunakan untuk mengetahui distribusi frekuensi tentang kecemasan, pengetahuan, perubahan fisik dan dukungan keluarga.

Tabel 1. Distribusi Frekuensi Responden Berdasarkan Kecemasan, pengetahuan, perubahan fisik dan dukungan keluarga di Desa Meunasah Dayah Kecamatan Peusangan Kabupaten Bireuen Tahun 2019.

\begin{tabular}{ccc}
\hline \multirow{2}{*}{ Analisis Univariat } & Jumlah & $\mathbf{( \% )}$ \\
\cline { 2 - 3 } & F & \\
Kecemasan & 51 & 31 \\
Tidak Cemas & 73 & 45 \\
Ringan & 39 & 24 \\
Sedang & & \\
Pengetahuan & 40 & 25 \\
Baik & 95 & 58 \\
Cukup & 28 & 17 \\
Kurang & & \\
Perubahan Fisik & 130 & 80 \\
Mengalami & 33 & 20 \\
Tidak Mengalami & & \\
Dukungan Keluarga & 100 & 61 \\
Mendukung & 63 & 39 \\
Tidak Mendukung & $\mathbf{1 6 3}$ & $\mathbf{1 0 0}$ \\
\hline Jumlah & &
\end{tabular}

Berdasarkan tabel diatas dari 163 responden, mayoritas responden memiliki tingkat kecemasan ringan yaitu sebanyak 73 responden (45\%). Mayoritas responden memiliki tingkat pengetahuan cukup sebanyak 95 responden (58\%). Mayoritas responden mengalami perubahan fisik yaitu sebanyak 130 responden (80\%). Mayoritas responden memiliki keluarga yang mendukung responden dalam menghadapi menopause sebanyak 100 responden (61\%).

Analisis Bivariat digunakan untuk mengetahui hubungan antara variabel independen terhadap variabel dependen dengan menggunakan chi-square pada tingkat kemaknaan 95\% atau nilai $(\alpha=0,05)$. Bila menunjukan nilai $\mathrm{p} \leq 0,05$ artinya ada hubungan bermakna atau signifikan. 
Journal of Healthcare Technology and Medicine Vol. 5 No. 2 Oktober 2019

Universitas Ubudiyah Indonesia

e-ISSN : 2615-109X

Tabel 2. Hubungan pengetahuan, perubahan fisik dan dukungan keluarga dengan kecemasan di Desa Meunasah Dayah Kecamatan Peusangan Kabupaten Bireuen Tahun 2019.

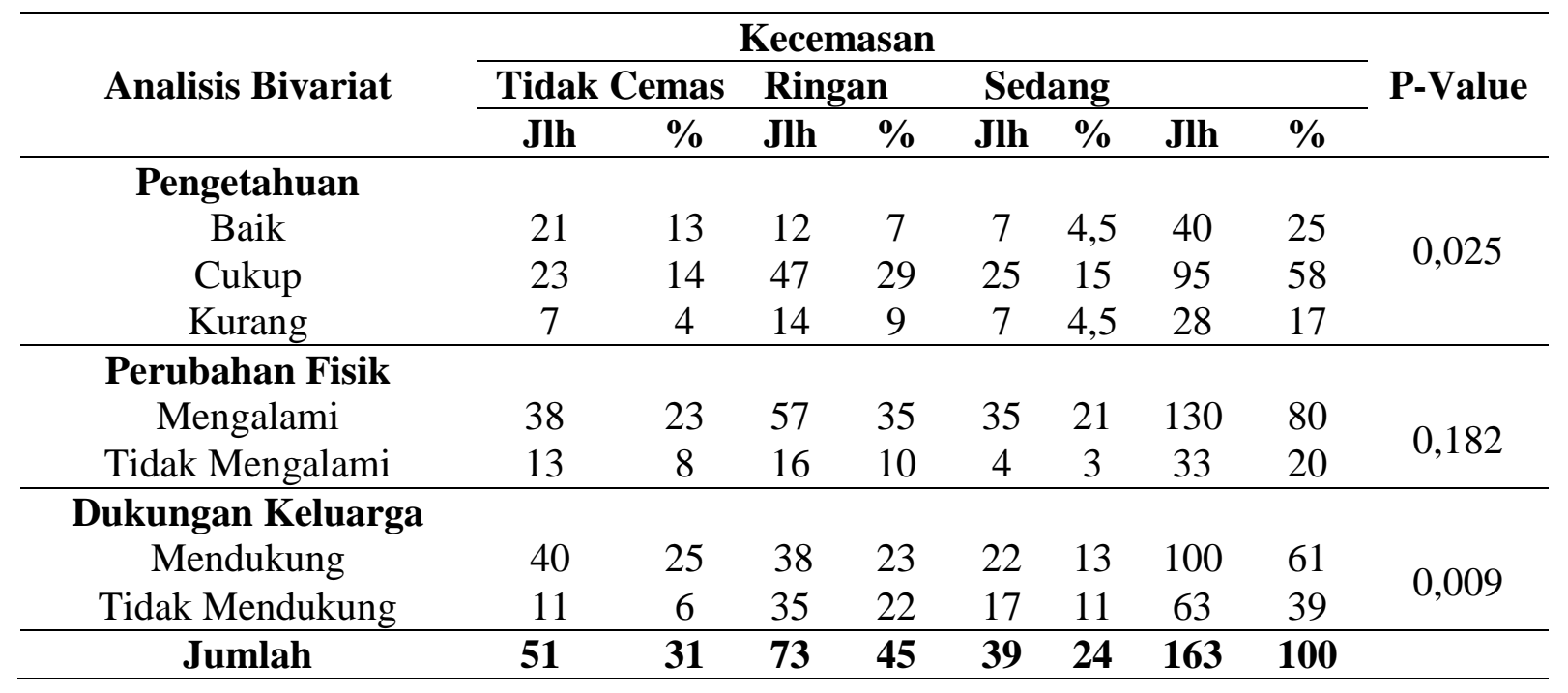

Berdasarkan uji silang diatas dapat dilihat bahwa dari 163 responden, mayoritas responden yang memiliki pengetahuan cukup adalah responden yang memiliki kecemasan ringan menjelang menopause yaitu sebanyak 47 responden (29\%).

Dari hasil uji chi square dengan tingkat kepercayaan 95\% $(\alpha=0,05)$ hasil perhitungan menunjukkan nilai $\mathrm{p}(0,025)<\mathrm{p}$ value $(0,05)$ berarti ha diterima dan h0 ditolak, artinya ada pengaruh antara pengetahuan dengan kecemasan dalam menghadapi menopause.

Berdasarkan uji silang diatas dari 163 responden, mayoritas yang mengalami perubahan fisik adalah responden yang memiliki tingkat kecemasan ringan menjelang menopause yaitu sebanyak 57 responden $(35 \%)$.

Dari hasil uji chi square dengan tingkat kepercayaan 95\% $(\alpha=0,05)$ hasil perhitungan menunjukkan nilai $\mathrm{p}(0,182)>\mathrm{p}$ value $(0,05)$ berarti h0 diterima dan ha ditolak, artinya tidak ada pengaruh antara perubahan fisik dengan kecemasan dalam menghadapi menopause.

Berdasarkan uji silang diatas dari 163 responden, mayoritas responden yang keluarganya mendukung adalah responden yang tidak mengalami kecemasan menjelang menopause yaitu sebanyak 40 responden $(25 \%)$.

Dari hasil uji chi square dengan tingkat kepercayaan 95\% $(\alpha=0,05)$ hasil perhitungan menunjukkan nilai $\mathrm{p}(0,009)<\mathrm{p}$ value $(0,05)$ berarti ha diterima dan h0 ditolak, artinya ada pengaruh antara dukungan keluarga dengan kecemasan dalam menghadapi menopause. 


\section{PEMBAHASAN}

Pengaruh pengetahuan terhadap kecemasan dalam menghadapi menopause di Desa Meunasah Dayah : Penelitian ini menunjukkan bahwa dari hasil penelitian, mayoritas responden memiliki pengetahuan cukup tentang menopause yaitu sebanyak 95 responden (58\%). Dilihat dari hasil uji silang, mayoritas responden yang memiliki pengetahuan cukup adalah responden yang memiliki kecemasan ringan dalam menghadapi masa menjelang menopause yaitu sebanyak 47 responden (29\%).

Dari hasil uji chi square dengan tingkat kepercayaan $95 \%(\alpha=0,05)$ hasil perhitungan menunjukkan nilai $\mathrm{p}(0,025)<\mathrm{p}$ value $(0,05)$ berarti ha diterima dan ho ditolak, artinya ada pengaruh antara pengetahuan dengan kecemasan dalam menghadapi menopause.

Wanita dengan pengetahuan kurang atau cukup (belum maksimal) mempunyai peluang 3 kali berisiko mengalami kecemasan dalam menghadapi menopause, dibandingkan dengan wanita yang memiliki pengetahuan yang baik (Lusiana, 2014).

Menurut Notoatmodjo (2010), pengetahuan merupakan hasil dari tahu yang dapat diperoleh dari panca indera seperi mata, telinga mulut, lidah, kulit dan lainnya. Pengetahuan yang baik akan menghasilkan perilaku yang baik, begitu pula sebaliknya perilaku yang tidak baik akan mempengaruhi perilaku seseorang menjadi tidak baik.

Asumsi peneliti, adanya pengaruh antara pengetahuan dengan kecemasan yang dialami responden dikarenakan responden sudah memiliki pengetahuan yang standar yaitu dalam batas cukup mengenai hal-hal yang berhubungan dengan menopause, sehingga kecemasan yang mereka alami hanya dalam batas ringan saja. Jika responden sudah mulai paham atau mengerti akan fenomenal menopause maka kecemasan yang mereka alami juga tidak perlu ditindaklanjuti.

Pengaruh perubahan fisik terhadap kecemasan dalam menghadapi menopause di Desa Meunasah Dayah : Penelitian ini menunjukkan bahwa dari hasil penelitian, mayoritas responden mengalami perubahan fisik yaitu sebanyak 130 responden (80\%). Dilihat dari hasil uji silang, mayoritas yang mengalami perubahan fisik adalah responden yang memiliki tingkat kecemasan ringan menjelang menopause yaitu sebanyak 57 responden (35\%).

Dari hasil uji chi square dengan tingkat kepercayaan $95 \%(\alpha=0,05)$ hasil perhitungan menunjukkan nilai $\mathrm{p}(0,182)>\mathrm{p}$ value $(0,05)$ berarti h0 diterima dan ha ditolak, artinya tidak ada pengaruh antara perubahan fisik dengan kecemasan dalam menghadapi menopause. 
Journal of Healthcare Technology and Medicine Vol. 5 No. 2 Oktober 2019

Universitas Ubudiyah Indonesia

e-ISSN : 2615-109X

Menurut Rosenthal (2010), menopause merupakan hal yang alamiah yang akan terjadi pada semua wanita yang ada didunia. Proses menopause terjadi disebabkan oleh penuaan pada diri wanita, dimana hormone esterogen yang sudah menurun akan mengganggu sistem resproduksi pada wanita menopause. Selain itu adanya pengaruh penurunan hormone estrogen membuat terjadinya perubahan pada fisik wanita menopause seperti kulit menjadi kendur, adanya rasa panas dimalam hari (hot flush) dan lainnya. (Dikutip dari Lusiana, 2014).

Beberapa gejala fisik yang dialami oleh seorang perempuan yang memasuki fase menopause yaitu rasa panas atau hot flues yang merupakan sensasi tiba-tiba panas dan berkeringat terutama pada tubuh bagian atas. Hot flashes terutama dan yang paling intensif terjadi pada wanita peri dan pasca menopause berkeringat saat malam hari, susah tidur, sakit kepala, kesusahan menahan buang air kecil, detak jantung meningkat, dan peningkatan berat badan. Selain itu juga disertai dengan beberapa gejala psikis yang menonjol berupa yang suasana hati yang berubah ubah, mudah tersinggung, emosi labil, merasa tidak berharga, dan munculnya kecemasan yang dapat mengganggu aktifitas sehari-hari (Nurpatminingsih, 2016).

Asumsi peneliti, tidak adanya pengaruh antara perubahan fisik dengan kecemasan menjelang menopause karena responden sudah memahami dan tahu akan perubahan yang dialami oleh mereka ketika akan mendekati fase menopause, mereka tahu perubahan usia yang semakin menua, sehingga lambat laun akan berubah fungsi dan kondisi yang tidak seperti muda dulu. Sehingga responden tidak mengalami kecemasan yang berlebihan dalam menghadapi menopause.

Pengaruh dukungan keluarga terhadap kecemasan dalam menghadapi menopause di Desa Meunasah Dayah : Penelitian ini menunjukkan bahwa dari hasil penelitian, mayoritas responden mendapat dukungan dari keluarga menjelang menopause. Dilihat dari hasil uji silang, mayoritas responden yang keluarganya mendukung adalah responden yang tidak mengalami kecemasan menjelang menopause yaitu sebanyak 40 responden $(25 \%)$.

Dari hasil uji chi square dengan tingkat kepercayaan 95\% $(\alpha=0,05)$ hasil perhitungan menunjukkan nilai $\mathrm{p}(0,009)<\mathrm{p}$ value $(0,05)$ berarti ha diterima dan ho ditolak, artinya ada pengaruh antara dukungan keluarga dengan kecemasan dalam menghadapi menopause.

Dukungan keluarga adalah bentuk sikap, tindakan penerimaan keluarga terhadap anggota keluargannya, berupa dukungan informasional, dukungan penilaian, dukungan instrumental dan dukungan emosional. Jadi dukunan keluarga adalah suatu bentuk hubungan interpersonal yang meliputi sikap, tindakan dan penerimaan terhadap anggota keluarga, sehingga anggota keluarga merasa ada yang memperhatikannya. Jadi dukungan sosial 
Journal of Healthcare Technology and Medicine Vol. 5 No. 2 Oktober 2019

Universitas Ubudiyah Indonesia

e-ISSN : 2615-109X

keluarga mengacu kepada dukungan-dukungan sosial yang dipandang oleh anggota keluarga sebagai sesuatu yang dapat diakses atau diadakan untuk keluarga yang selalu siap memberikan pertolongan dan bantuan jika diperlukan (Utini, 2015).

Menurut Rosenthal (2009), pada masa menopause dukungan sangat dibutuhkan. Banyak wanita mengalami kecemasan pada masa menopause disebabkan oleh karena mereka takut kehilangan rasa sayang dari suami atau keluarga karena sudah tidak menarik lagi dan tidak berguna lagi (Dikutip dari Lusiana, 2014).

Asumsi peneliti, adanya pengaruh antara dukungan keluarga dengan kecemasan menjelang menopause dikarenakan responden mendapatkan dukungan dari keluarga baik secara psikologis ataupun dukungan lainnya sehingga responden tidak mengalami gangguan kecemasan dalam menghadapi masa-masa menjelang menopause. Selain itu mereka juga banyak disibukkan dengan kegiatan seperti pengajian, acara posyandu lansia didesa sehingga mereka sudah banyak mendapatkan informasi tentang menopause pada saat acara tersebut.

\section{KESIMPULAN}

Kesimpulan penelitian ini ada pengaruh pengetahuan dan dukungan keluarga dengan kecemasan dalam menghadapi menopause di Desa Meunasah Dayah Kecamatan Peusangan Kabupaten Bireuen Tahun 2019. Tetapi tidak ada pengaruh perubahan fisik dengan kecemasan dalam menghadapi menopause di Desa Meunasah Dayah Kecamatan Peusangan Kabupaten Bireuen Tahun 2019.

\section{SARAN}

Disarankan kepada responden agar meningkatkan lagi pengetahuan khususnya tentang tanda serta gejala yang terjadi menjelang menopause sehingga dapat mengurangi rasa cemas dan khawatir yang dirasakan dan diharapkan Kepada tenaga kesehatan untuk memberikan pelayanan, pendidikan, penyuluhan kepada masyarakat terkait dengan menopause.

\section{DAFTAR PUSTAKA}

Adiba. 2014. Konsep Menopause. Jurnal Kesehatan : Universitas Sumatera Utara.

Agria. 2012. Gizi Reproduksi. Fitramaya. Yogjakarta.

Anis. 2016. Konsep Teoritis Menopause. Jurnal Kesehatan : Fakultas Kedokteran Universitas Sumatera Utara.

Horhoruw. 2016. Hubungan Paritas Dengan Tingkat Kecemasan Ibu Di Puskesmas Jetis Kota Yogyakarta. Jurnal Kebidanan : Universitas Aisyiyah Yogyakarta. 
Journal of Healthcare Technology and Medicine Vol. 5 No. 2 Oktober 2019

Universitas Ubudiyah Indonesia

e-ISSN : 2615-109X

Iman, M. 2016. Panduan Penyusunan Karya Tulis Ilmiah Bidan Kesehatan. Cita Pusaka: Medan.

2014. Pemanfaatan SPSS Dalam Penelitian Bidang Kesehatan \& Umum. Cita Pusaka: Medan.

Kalo. 2014. Hubungan Karakteristik Ibu Dengan Tingkat Kecemasan Di Poli Kia Puskesmas Tuminting. Surakarta. Jurnal kesehatan : Fakultas Kedokteran Universitas Sam Ratulangi Manado.

Kemkes RI. 2017. Profil Kesehatan Tahun 2017. Kementrian Kesehatan Republik Indonesia. Jakarta.

Kulsum. 2017. Kecemasan Wanita Pada Masa Menopause Berdasarkan Tingkat Ekonomi. Jurnal Kesehatan Vol. 1 No.2 (2017) 100-106. Semarang.

Kumalasari. 2012. Kesehatan Reproduksi Untuk Mahasiswa Kebidanan dan Keperawatan. Salemba Medika. Jakarta.

Lusiana. 2014. Faktor-faktor yang berhubungan dengan kecemasan wanita dalam menghadapi menopause di Puskesmas Pekan Baru tahun 2014. Jurnal Kesehatan Komunitas Vol. 2 No.5 (2014). Pekan Baru.

Manuaba. 2009. Memahami Kesehatan Reproduksi Wanita. EGC. Jakarta.

Nafis. 2016. Telaah Pustaka Sindrome Menopause. Jurnal Kesehatan. Jakarta.

Notoatmodjo. 2010. Pendidikan dan Perilaku Kesehatan. Rineka Cipta. Jakarta.

Nuratminingsih. 2016. Hubungan Antara Kesiapan Menopause Dengan Kecemasan Menghadapi Menopause Pada Ibu Pkk Di Desa Gentan Kecamatan Bendosari Kabupaten Sukoharjo. Jurnal Kesehatan : Fakultas Ilmu Kesehatan. Surakarta.

Proverawati. 2010. Menopause dan Sindrome Premenopause. Nuha Medika. Yogyakarta.

Rukiah. 2012. Asuhan Kebidanan IV Patologi. Trans Info Media. Jakarta.

Rusna. 2017. Konsep Perubahan Fisiologis. Jurnal Kesehatan. Jakarta.

Utini. 2015. Konsep Dukungan Keluarga. Jurnal Psikologi. Ponorogo.

Yuliasari. 2017. Kematangan Emosi dan Kecemasan. Jurnal Psikologi, Vol. 2, No.1 Juli 2017, ISSN : 2528-2735. Jambi.

Zamriati. 2013. Faktor-faktor yang berhubungan dengan Kecemasan Puskesmas Tuminting. Program Studi Ilmu Keperawatan Kedokteran Universitas Samratulangi Manado. Jurnal Keperawatan (e-Kp) Vol.1 No.1 Agustus 2013. 